\title{
Endoscopic resection of colloid cyst: long-term followup with 63 patients
}

\author{
Albert Isaacs ${ }^{*}$, Walter Hader, Mark Hamilton \\ From Hydrocephalus 2015 \\ Banff, Canada. 18-21 September 2015
}

\section{Introduction}

Colloid cysts of the third ventricle are rare, histologically benign lesions that can be associated with obstructive hydrocephalus. Endoscopic removal developed as an alternative to microsurgical craniotomy as a less invasive surgical treatment. This review examines the endoscopic surgical experience for a consecutive series of patients with colloid cyst of the third ventricle.

\section{Methods}

Patients with a diagnosis of "colloid cyst of the third ventricle" who were treated in Calgary between January 1994 and July 2014 were reviewed using a clinic database and registry.

\section{Results}

93 patients were identified. 30 patients without hydrocephalus underwent serial MRI and clinical observation with one patient developing hydrocephalus leading to surgical treatment. 63 patients underwent endoscopic treatment of their colloid cyst (male $=34$; female $=29$ ). The mean age at diagnosis was 46.3 years. 2 patients had been previously treated with other surgical approaches. All surgically treated patients had hydrocephalus and hydrocephalus resolved in all 63 patients. 1 patient sustained an injury to the internal capsule with transient hemiparesis. Mean followup was 8.8 years (range 0.1-20.2 years). 2 patients experienced colloid cyst recurrence treated with a second endoscopic removal.

\section{Conclusion}

Endoscopic treatment of third ventricle colloid cysts can be performed with low risk as an alternative to microsurgical resection.

\footnotetext{
* Correspondence: akm.isaacs@gmail.com University of Calgary, Canada
} creativecommons.org/licenses/by/4.0), which permits unrestricted use, distribution, and reproduction in any medium, provided the original work is properly cited. The Creative Commons Public Domain Dedication waiver (http://creativecommons.org/publicdomain/ zero/1.0/) applies to the data made available in this article, unless otherwise stated.

\section{and take full advantage of:}

- Convenient online submission

- Thorough peer review

- No space constraints or color figure charges

- Immediate publication on acceptance

- Inclusion in PubMed, CAS, Scopus and Google Scholar

- Research which is freely available for redistribution

Submit your manuscript at
www.biomedcentral.com/submit

C Biomed Central \\ () Biomes Central}

\section{References}

Honey C R, Yeomans W, Jayaraman J, Isaacs A, Honey C M: The Dying Art of Percutaneous Cordotomy in Canada. Journal of Palliative Medicine 2014, 17(5), PMID: 24717005.

increases High-Fat Diet Intake and Body Weight in

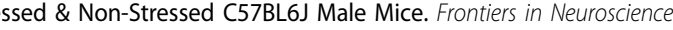
King S J, Isaacs A M, O'Farell E, Abizaid A: Motivation to Obtain Preferred Foods is Enhanced by Ghrelin in the Ventral Tegmental Area. Hormones

doi:10.1186/2045-8118-12-S1-P19

Collo this article as: Isaacs et al.: Endoscopic resection of colloid long-term followup with 63 patients. Fluids and Barriers of the CNS 2015 12(Suppl 1):P19.
Published: 18 September 2015 